JRTIE: Journal of Research and Thought of Islamic Education

Vol. 1, No. 1, 2018

\title{
PENGAJIAN KITAB KIFAYAH WA MINHAJ AL-AHFIYA JAMAAH MASJID DARUL MUTTAQIN KOTA PONTIANAK
}

\author{
Abdusy Syakur, Ma'ruf dan Sudi Yahya Husein \\ IAIN Pontianak, Indonseia \\ super123ptk@gmail.com
}

\begin{abstract}
This research was conducted because the implementation of the study taught by KH. Syamsuddin Husein al-Hafidz using Book of the Kifayah al-Atqiya 'Wa Minhaj al-Asfiya' that carried out every Sunday, the Maghrib about two years followed by few students and mostly by men. The study done was still rigid and monotonous, which eventually can lead to boredom in the congregation. Research uses descriptive method with a qualitative approach. The technique of checking validity of the data using triangulation and member checking. Based on the results of the data obtained by the researchers, the following conclusions are produced: 1) The objectives obtained in the study of the book Kifayah al-Atqiya 'Wa Minhaj al-Asfiya' a) Assembly of science, b) Advice, and c) Arguing while for the long-term goal of worshiping God alone. 2) The material presented nine suluk (paths) to Allah, namely: a) At-Taubah, b) Al-Qana'ah, c) Az-Zuhud, d) Learning science Syar' $i$, e) Maintain the sunnah of the Prophet, f) AtTawaqal, g) Al-Ikhlas, f) Al-Uzlah (aloof), and g) Keep time with dhikr. 3) The method used by the bandongan method.
\end{abstract}

Keywords: Recitation, Yellow Book, Mosque Darul Muttaqien

Abstrak: Penelitian ini dilatarbelakangi oleh kondisi Ta'lim yang diisi oleh KH. Syamsuddin Husein al-Hafidz dengan kajian kitab kuningnya yaitu kitab Kitab Kifayah al-Atqiya' Wa Minhaj al-Asfiya' nya di Masjid Darul Muttaqien, Pontianak, di mana ta'lim ini dilakukan setiap Ahad, ba'da Maghrib kurang lebih dua tahunan hanya diikuti oleh sedikit jamah dan hampir semua jamaah laki-laki. Penelitian ini menggunakan metode deskriptif dengan pendekatan kualitatif. Tehnik pengecekan keabsahan data menggunakan triangulasi dan member check. Berdasarkan hasil data yang diperoleh peneliti, menghasilkan kesimpulan sebagai berikut: 1) Tujuan yang didapatkan dalam pelaksanaan kajian a) Majelis ilmu, b) Nasehat, dan c) Berdebat sedangkan untuk tujuan jangka panjangnya yaitu untuk beribadah kepada Allah semata. 2) Materi yang disampaikan ada sembilan suluk (jalan)menuju Allah yaitu: a) At-Taubah, b) Al-Qana'ah, c) Az-Zuhud, d) Belajar ilmu Syar'i, e) Menjaga sunnahsunnah Nabi,f) At-Tawaqal, g) Al-Ikhlas, f) Al-Uzlah (menyendiri), dan g) Menjaga waktu dengan dzikir. 3) Metode yang digunakan dalam pelaksanaan kajian yaitu dengan metode bandongan. Kyai membacakan, menerjemahkan, menerangkan, kalimat demi kalimat kitab itu dengan makna dan menjelaskan berdasarkan contoh kehidupan sehari-hari. Ta'lim yang dilakukan masih bersifat kaku dan monoton, yang akhirnya nanti dapat menimbulkan kebosanan pada jama'ah.

Kata Kunci: Pengajian, Kitab Kuning, Masjid Darul Muttaqien 


\section{A. Pendahuluan}

Pendidikan merupakan hal yang sangat penting yang menjadi urat nadi kehidupan setiap manusia apalagi sebagai seorang muslim maupun muslimah. Baik sejak dari dalam kandungan hingga ia meninggal, kecil, remaja, dewasa maupun orang tua, laki-laki ataupun perempuan. Karena sebagai bekal kehidupan menuju alam selanjutnya, yaitu akhirat.

Al-Qur'an dan As-Sunnah yang shahih merupakan pedoman, baik secara personal maupun sosial kemasyarakatan. Keduanya menjamin kebahagian dunia dan akhirat. Berpaling dari keduanya merupakan penyebab dari kesengsaraan di dunia dan akhirat. Sama saja baik itu bagi orang yang berpaling dari keduanya dan menggantinya dengan sesuatu yang lain, berupa hadist-hadist palsu dan bait-bait syair buatan manusia, ataupun bagi orang yang meninggalkan keduanya secara keseluruhan dan merasa cukup dengan sistem dunia dan hukum-hukum buatan manusia. ${ }^{109}$

Maka tidaklah dibenarkan mendekatkan diri kepada Allah dengan caracara ibadah yang tidak disyari'atkan oleh Allah. Kita juga tidak boleh berlebihlebihan dan melampaui batas dalam perkara yang disyari'atkan oleh Allah. Petunjuk Nabi Muhammad SAW dan cara ibadahnya adalah contoh yang ideal dalam perkara ini. Maka, tidak diperkenankan bagi seorangpun dari umat Rasulullah untuk menambahnya ataupun beranggapan bahwasannya dia beribadah lebih sempurna dari Rasulullah. Orang-orang mukmin tidak mesti seluruhnya pergi ke medan perang, akan tetapi haruslah ada segolongan yang pergi untuk berjihad di medan perang, dan golongan lain yang tinggal untuk memperdalam ilmu agama. Apabila orang yang berjihad di medan perang telah kembali, maka tugas bagi orang yang tinggal dan belajar untuk memberikan pemahaman dan mengajarkan kepada mereka yang berjihad apa yang Allah turunkan dari perkara agama, serta mengenai haram dan haram. ${ }^{110}$

\footnotetext{
${ }^{109}$ Majalah As-Sunnah, (Jakarta: 2015), hlm. 24.

110 Ahmad Farid, Bahrur Ra'iq Zuhdi war Raqa'iq (Zuhud dan Kelembutan Hati), (Depok: Pustaka Khazanah Fawa'id, 2016), hlm. 46.
} 
Pahala ilmu senantiasa sampai kepada seseorang setelah kematiannya, selama ilmu itu masih memberikan manfaat. Maka seolah-olah dia masih hidup, tidak henti-hentinya beramal, hingga bibirnya menjadi hitam dengan berdzikir dan memuji Allah. Pahala itu terus mengalir ketika pahala lainnya terputus bagi manusia dalam kehidupan yang kedua. ${ }^{111}$

Karena begitu berperan pentingnya ilmu bagi manusia, Allah Swt menganugerahkan akal agar manusia bisa menyerap berbagai ilmu yang telah ditebar-Nya. ${ }^{112}$ Sehingga ia mampu memperoleh sesuatu untuk kepentingan dunianya maupun kebutuhan akhiratnya. Sebab, untuk meraih dunia dan akhirat sangat diperlukan adanya ilmu. Ilmu sangat menunjang kehidupan setiap insan karena bisa mendapatkan banyak hal. Itulah sebabnya, dalam sebuah hadist yang diriwayatkan oleh Dailami, dikisahkan bahwa Nabi Sulaiman lebih memilih ilmu ketimbang harta benda maupun kerajaan yang ditawarkan kepadanya. Sebab, dengan ilmu yang dipilihnya, akhirnya ia mendapatkan harta benda dan kerajaan. ${ }^{113}$ Oleh karena itu, sangat pantas jika Allah Swt meninggikan derajat hamba-Nya yang berilmu lebih tinggi dibanding yang tidak berilmu. Sebab, dengan ilmu yang dimiliki, seseorang bisa sedikit menerjemahkan yang dikehendaki oleh Allah Swt di dunia, sehingga yang dilakukannya sesuai dengan hukum-Nya.

Meskipun ilmu mempunyai peranan penting bagi kehidupan manusia, tetapi tidak setiap manusia menyadari terhadap tuntutan itu. Banyak di antara mereka yang tidak tergerak untuk memeperkaya wawasan dan pengetahuannya sehingga kehidupannya kurang berwarna. Mereka merasa sudah cukup dengan sedikit ilmu yang dimilikinya dan merasa paling pintar. Bahkan, tidak sedikit yang cenderung bermusuhan dengan ilmu dan pengetahuan baru yang hadir dalam kehidupannya, sehingga pikirannya

\footnotetext{
111 Ibid., hlm. 49.

112 Quraish Shihab, Ensiklopedia Al-Qur'an (Kajian Kosakata), (Jakarta: Lentera Hati, 2007), hlm. 64.

113 Fahrudin Ghozy, Memungut Amalan Recehan (Rahasia di Balik Amal-Amal Recehan), (Yogyakarta: Safirah, 2012), hlm. 49.
} 
menjadi cupet $^{114}$ dan cepat menghakimi orang lain. Sebab, ia tidak menyadari bahwa ada cara lain selain apa yang selama ini diketahui dan diyakininya. Padahal menambah dan mencari ilmu itu wajib hukumnya bagi setiap muslim. ${ }^{115}$ Nah hal ini sejalan dan selaras dengan apa yang terjadi di saat ini di Indonesia khususnya di Kota Pontianak terlebih lagi perkembangan ilmu agama yang begitu pesat, kegiatan majelis-majelis di masjid-masjid menjadi sarana dalam mencari ilmu. Salah satu masjid yaitu Darul Muttaqien, untuk saat ini kegiatan ta'lim yang diadakan oleh bidang Ibadah dan Dakwah setiap hari kecuali Kamis dan Sabtu $b a^{\prime} d a$ Magrib dan sebulan sekali $b a^{\prime} d a$ Subuh di minggu ke dua ataupun ke tiga.

Ta'lim-ta'lim yang sarat dengan ilmu agama baik dari segi Tauhid atau Tasawuf, Fiqh, Al-Qur'an dan Hadist maupun kajian-kajian kitab kuningnya yang menghadirkan ustadz-ustadz yang mumpuni di bidangnya masingmasing. ${ }^{116}$ Ta'lim yang dilakukan setiap hari Minggu yaitu $b a^{\prime} d a$ Maghrib kurang lebih berjalan hampir dua tahun-nan yang diisi oleh al-Ustadz KH. Syamsuddin Husein al-Hafidz dengan kajian kitab kuningnya yaitu kitab Kifayah al-Atqiya' Wa Minhaj al-Așfiya'-nya yang populer ditelinga orang-orang tua maupun sesepuh-sesepuh. Kyai yang mengajar ta'lim dalam penelitian ini, menggunakan kitab kuning tanpa syakal tidak seperti ustadz-ustadz yang mengajar yang menggunakan kitab terjemahan pada ta'lim-ta'lim lainnya. ${ }^{117}$

Namun dalam pelaksanaannya, ta'lim yang dilakukan masih bersifat kaku dan monoton, yang akhirnya nanti dapat menimbulkan kebosanan pada jama'ah. Hal ini terlihat jelas dari kalangan ibu-ibu maupun remaja-remajanya sendiri jarang hadir bahkaan tidak sama sekali, padahal ta'lim ini bersifat untuk umum siapa saja boleh datang ke ta'lim tersebut. Oleh karena itu, kajian dalam tulisan ini penting untuk dikaji, terutama kaitannya dengan materi, metode,

114 Menurut KBBI berarti berpikir sempit atau dangkal.

115 Ibid., hlm. 51.

116 Berdasarkan Jadwal Kajian Rutin Masjid Darul Muttaqien tahun 2017.

117 Berdasarkan hasil observasi peneliti selama hampir satu tahun dan peneliti menjadi salah satu penasehat di kepengurusan RISDAQIEN (Remaja Islam Darul Muttaqien) dan saat ini menjadi pengurus masjid di bagian kebersihan. 
JRTIE: Journal of Research and Thought of Islamic Education

Vol. 1, No. 1, 2018

dan tujuan yang didapatkan dari pelaksanaan kajian kitab Kifayah al-Atqiya' Wa Minhaj al-Așfiya' oleh KH. Syamsuddin Husein al-Hafidz.

\section{B. Metode Penelitian}

Dalam penelitian ini, peneliti menggunakan metode deskriptif, penelitian yang bertujuan membuat deskriptif secara tematis, faktual dan akurat tentang fakta-fakta dan sifat-sifat populasi atau objek tertentu dengan menggunakan metode riset kualitatif karena di dalamnya menggambarkan keadaan atau kejadian objek penelitian secara aktual dan akurat sesuai dengan fakta yang tampak di lapangan ${ }^{118}$. Sedangkan pendekatan yang digunakan ialah pendekatan kualitatif. Hal ini dikarenakan, penelitian ini lebih cenderung berhubungan dengan gejala sosial atau perilaku sosial yang terjadi di lapangan. Alasan peneliti tersebut berdasarkan pendapat M. Subana dan Sudrajat,119 bahwa pendekatan kualitatif cenderung berkembang dan banyak digunakan dalam ilmu-ilmu sosial yang berhubungan perilaku sosial atau manusia, dengan berbagai argumentasi tertentu.

Lokasi penelitian yang akan dilakukan oleh peneliti adalah di masjid Darul Muttaqien khususnya pada ta'lim hari Minggu $b a^{\prime} d a$ Maghrib. Masjid ini terletak di jalan Tabrani Ahmad depan komplek Mandau Permai kelurahan Sungai Jawi Dalam, Pontianak Barat, Kota Pontianak. Masjid ini dipilih karena masjid ini berlokasi strategis ditengah kota yang padat penduduk dan sering digunakan untuk berbagai kegiatan dan peneliti juga sebagai pengurus masjid tersebut. Data yang diperoleh dari penelitian ini adalah berupa hasil dari yang dilihat, didengar, dan dipahami oleh peneliti dari sumbernya yaitu ustadz yang menyampaikan ta'limnya dari kajian kitab Kifayah al-Atqiya' Wa Minhaj al-Asfiya' nya sebagai sumber data primer dan jamaah Darul Muttaqien sebagai sumber data sekunder. Untuk memperoleh data yang sesuai dengan fokus yang akan diteliti, tentunya memerlukan teknik pengumpulan data yang tepat sesuai

\footnotetext{
118 Margono, S., Metodologi Penelitian Pendidikan, (Jakarta: Rineka Cipta, 2000), hlm. 82.

119 M. Subana dan Sudrajat, Dasar-dasar Penelitian Ilmiah, (Bandung: Pustaka Setia, 2009), hlm. 13.
} 
JRTIE: Journal of Research and Thought of Islamic Education

Vol. 1, No. 1, 2018

dengan fokus yang akan diteliti. Oleh karena itu, teknik pengumpul data yang akan dipergunakan dalam penelitian ini adalah teknik observasi partisipan, wawancara mendalam dan dokumentasi.

\section{Pengajian Kitab Kuning Kifayah al-Atqiya' Wa Minhaj al-Asfiya'}

Pelaksanaan kajian kitab Kifayah al-Atqiya' Wa Minhaj al-Așfiya' oleh KH. Syamsuddin Husein al-Hafidz di masjid Darul Muttaqien ini telah berlangsung selama lebih kurang tiga tahun dimulai sejak tahun 2015 tepatnya bulan Syawal tahun $1436 \mathrm{H}$ hingga saat ini. Pelaksanaan kajian kitab ini dipelopori oleh masukan-masukan dari yayasan maupun pengurus masjid Darul Muttaqien maka ta'lim harian yang menjadi salah satu program dari bidang Ibadah dan Dakwah yang diketuai oleh Bapak H. Ruslan Abdul Gani. Maka al-Ustadz KH. Syamsuddin Husein al-Hafidz yang tinggal di daerah Punggur, Kubu Raya tepatnya di jalan Parit Husein, beliau adalah salah satu ustadz yang mengisi ta'lim setiap hari Minggu $b a^{\prime} d a$ Magrib kurang lebih sekitar 30 menit ta'lim ini berlangsung dengan kajian kitabnya yaitu Kifayah al-Atqiya' Wa Minhaj alAșfiya'.

Kaku dan monoton adalah yang dilihat oleh peneliti setiap kali mengikuti ta'lim ini hal ini dilihat dari tingkah laku jama'ah yang beragam, ada yang hanya mendengar, ada yang serius bahkan ada yang tidur, tetapi ada pula yang mendengarkan dan bertanya itupun hanya sesekali karena ustadznya sendiri jarang memberikan kesempatan untuk jama'ahnya bertanya.

Kegiatan $\mathrm{ta}^{\prime} \mathrm{lim}$ ini hanya dihadiri oleh kalangan bapak-bapak saja yang kebanyakan mereka adalah pensiunan negeri maupun swasta sementara untuk kalangan ibu-ibu, remaja maupun anak-anak jarang hadir padahal ta'lim ini bersifat untuk umum maka siapa saja boleh datang untuk menambah ilmu melalui kegiatan $t a^{\prime} l i m$ ini.

\section{D.Materi Kajian Kitab Kuning Kifayah al-Atqiya' Wa Minhaj al-Asfiya'}

Adapun materi yang disampaikan dalam pelaksanaan kajian kitab Kifayah al-Atqiya' Wa Minhaj al-Așfiya' oleh KH. Syamsuddin Husein al-Hafidz 
ada sembilan wasiat. Di dalam kitab ini pada awal pembahasannya disebutkan dalam sebuah kalimat yaitu "barang siapa bermaksud menempuh jalan para kekasih Allah maka hendaknya ia menjaga wasiat-wasiat sembilan".

Sembilan wasiat untuk suluk menuju Allah diantaranya:

1. At-Taubah (Halaman 14, Kitab Kifayah al-Atqiya' Wa Minhaj al-Așfiya')

2. Al-Qana'ah (Halaman 18, Kitab Kifayah al-Atqiya' Wa Minhaj al-Așfiya')

3. Az-Zuhud (Halaman 20, Kitab Kifayah al-Atqiya' Wa Minhaj al-Asfiya')

4. Belajar ilmu Syar'i (Halaman 23, Kitab Kifayah al-Atqiya' Wa Minhaj alAsfiya')

5. Menjaga sunnah-sunnah Nabi (Halaman 25, Kitab Kifayah al-Atqiya' Wa Minhaj al-Așfiya')

6. At-Tawaqal (Halaman 29, Kitab Kifayah al-Atqiya' Wa Minhaj al-Așfiya')

7. Al-Ikhlas (Halaman 32, Kitab Kifayah al-Atqiya' Wa Minhaj al-Asfiya')

8. Al-Uzlah (menyendiri), (Halaman 37, Kitab Kifayah al-Atqiya' Wa Minhaj al-Așfiya')

9. Menjaga waktu dengan dzikir (Halaman 41, Kitab Kifayah al-Atqiya' Wa Minhaj al-Așfiya')

Kesembilan wasiat inilah yang terdapat didalam kitab Kifayah al-Atqiya' Wa Minhaj al-Așfiya' yang dijadikan materi oleh KH. Syamsuddin Husein alHafidz dalam menyampaikan ta'limnya di masjid Darul Muttaqien.

Kajian di masjid tentang kitab kuning yang diajarkan ustadz itu sendiri tergantung kebijakan pada pengurus masjid itu sendiri namun mereka lebih mengedepankan materi fiqh, tauhid, tasawuf dan etika serta tarikh dan balaqhah. Kitab-kitab klasik yang diajarkan umumnya di pesantren dapat digolongkan kepada 8 kelompok: nahwu dan sharaf, fikih, ushul fiqh, hadist, tafsir, tauhid, tasawuf dan etika, serta cabang-cabang ilmu lainnnya seperti tarikh dan balaqhah. Kesemuanya ini dapat pula digolongkan kedalam tiga kelompok yaitu: 1. Kitab-kitab dasar; 2. Kitab-kitab tingkat menengah; 3. Kitab-kitab besar. Untuk kitab Kifayah al-Atqiya' Wa Minhaj al-Așfiya' ini yang merupakan syarah atau ulasan dari kitab Hidayah al-Atqiya' Ila Thariqil Auliya', tentang 
materi tasawuf atau tauhid yaitu kitab yang berisikan sembilan suluk atau jalan menuju Allah. ${ }^{120}$ Kitab ini digunakan karena merupakan materi yang umum dan dikuasai oleh KH. Syamsuddin Husein al-Hafidz

\section{E. Metode Pembelajaran Kitab Kuning Kifayah al-Atqiya' Wa Minhaj al-}

Asfiya'

Metode pembelajaran adalah suatu cara pembelajaran yang penerapannya di arahkan untuk mencapai tujuan-tujuan yang dikehendaki sesuai dengan tujuan yang dirumuskan dalam program pembelajaran. Kitab kuning pada umumnya berbahasa Arab dan tidak mempunyai tanda baca. Maka dibutuhkan juga suatu metode untuk mengajarkan bagaimana kitab tersebut dapat dibaca oleh para santri, dan sebelum menterjemahkan dan menguraikan materi pembelajaran kitab kuning, sudah barang tentu dibahas tata bahasanya. Untuk mendalami kitab-kitab klasik tersebut, biasanya dipergunakan sistem weton dan sorogan, atau lebih dikenal dengan sorogan dan bandongan. ${ }^{121}$

Pada pengajaran dalam sistem sorogan, santri satu per satu secara bergiliran menghadap kyai dengan membawa kitab tertentu. Kyai membacakan beberapa baris dari kitab itu dan maknanya, kemudian santri mengulangi bacaan kyainya. Biasanya sistem sorogan dilakukan oleh santri yang masih yunior dan terbatas pada kitab-kitab yang kecil saja. Sistem ini memungkinkan seorang guru mengawasi, menilai, dan membimbing secara maksimal kemampuan seorang murid dalam menguasai berbahasa Arab. ${ }^{122}$ Adapun sistem yang digunakan adalah bandongan. Kyai membacakan isi kitab itu dengan makna dan penjelasan secukupnya, sementara para santri mendengar dan mencatat penjelasan kyai di pinggir halaman kitabnya. Di Masjid Darul Muttaqien ini al -Ustadz KH. Syamsuddin al-Hafidz melalui kitab Kifayah al-

\footnotetext{
${ }^{120}$ Berdasarkan wawancara dengan pengurus masjid pada tanggal 15 Agustus 2017.

${ }^{121}$ Martin Van Bruinessen, Kitab Kuning, Pesantren dan Tarekat, (Bandung: Mizan, 1999), hlm. 60.

122 Departemen Pendidikan Diniyah dan Pondok Pesantren, Depag RI., Jurnal Pondok Pesantren (Mihrab), (Jakarta: CV. Kaula Muda, 2006), hlm, 70.
} 
Atqiya' Wa Minhaj al-Așfiya' menggunakan sistem bandongan hal ini hampir serupa yang dilakukan di pesantren. Perbedaanya terletak pada santri yang mencatat penjelasan kyai di pinggir halaman kitabnya karena memegang sendiri kitabnya sedangkan kyai maupun ustadz yang mengajar di masjid membacakan isi kitab itu dengan makna dan menjelaskan berdasarkan contoh kehidupan sehari-hari. Jamaah hanya mendengar, tanpa mencatat sendiri dikarenakan belum ditemukannya kitab terjemahan di dalam bahasa Indonesia untuk kitab Kifayah al-Atqiya' Wa Minhaj al-Așfiya' ini. Cara belajar seperti ini paling banyak dilakukan di pesantren dan juga diterapkan oleh Ustadz KH. Syamsuddin al-Hafidz karena merupakan metode yang mudah diterapkan dalam kajian ini ${ }^{123}$

\section{F. Tujuan Pembelajaran Kitab Kuning Kifayah al-Atqiya' Wa Minhaj al-} Asfiya'

Tujuan di dalam pelaksanaan kajian kitab Kifayah al-Atqiya' Wa Minhaj al-Asfiya' oleh KH. Syamsuddin Husein al-Hafidz ini ada dua yang pertama yaitu jangka pendek dan jangka panjang124. Jadi adapun tujuan jangka pendek kita mempelajari kitab tasawuf ini, pertama kita membudayakan menghidupkan sunnah Rasulullah SAW, yang mana Rasulullah memerintahkan kita untuk giat belajar agama menuntut ilmu sampai disebutkan dalam satu hadist, "Apabila datang kepadaku hari yang tidak bertambah ilmu kepadaku mendekatkan diri kepada Allah maka tidak ada berkah terbit matahari pada hari itu".

Jadi kebiasaan kita untuk menghadiri majelis ilmu itu adalah salah satu misi baginda Rasul mengenalkan umat Islam khususnya dan umat manusia pada umumnya ke jalan Allah,125 karena Allah memerintahkan "Ajaklah orang ke jalan Tuhanmu dengan hikmah dengan bijaksana dengan argumentasi yang kuat" dan

${ }^{123}$ Hasil wawancara dengan Ustadz KH. Syamsuddin al-Hafidz pada 15 Agustus 2017 di Masjid Darul Muttaqien.

${ }^{124}$ Hasil wawancara dengan Ustadz KH. Syamsuddin al-Hafidz pada 15 Agustus 2017 di Masjid Darul Muttaqien.

125 Ritonga dan Jafar Syahbuddin, "Designing Curriculum, Capacity of Innovation, and Performances: A Study on the Pesantrens in North Sumatra," dalam MIQOT: Jurnal Ilmu-Ilmu Keislaman, No. 40, No. 1, 2016, hlm. 2. 
santri mesti memahami ilmu-ilmu agama Islam itu sendiri dari sumber aslinya yaitu Al-Qur'an dan Sunnah yang telah dijabarkan oleh ulama-ulama terdahulu dalam kitab-kitab klasik berbahasa Arab dengan segala cabangnya adalah merupakan unsur pokok dari suatu pesantren. ${ }^{126}$ Selanjutnya ialah nasehat yang baik (tausiyah) dan berdebat dengan cara yang lebih baik apabila ada orang yang menentang pendapat tersebut. 127

Kitab ini mengajarkan tentang tasawuf dengan cara ini kita semakin mendekat kepada Allah ${ }^{128}$, selain itu pelaksanaan kajian kitab ini tujuan jangka panjangnya ialah sebagai lembaga dakwah dan lembaga pendidikan non formal. Fleksibelitas majelis ta'lim inilah yang menjadi kekuatan sehingga mampu bertahan dan merupakan lembaga pendidikan Islam yang paling dekat dengan umat (masyarakat). ${ }^{129}$ Adapun tujuan jangka panjangnya yaitu dengan mengkaji kitab Kifayah al-Atqiya' Wa Minhaj al-Așfiya' ini kita makin memahami tujuan hidup kita diciptakan oleh Allah yang mana kita diciptakan untuk beribadah.

\section{G.Kesimpulan}

Pelaksanaan Pembelajaran Kitab Kuning Kifayah al-Atqiya' Wa Minhaj alAșfiya' merupakan program masjid Darul Muttaqien Pontianak yang rutin dilaksanakan untuk meningkatkan keimanan masyarakat. Kelemahan kajian ini adalah pengajaran yang kaku dan membosankan dengan menggunakan satu metode pengajaran sehingga jamaahnya berjumlah sedikit dan mayoritas lakilaki. Dengan tujuan kajian untuk memperdalam ilmu dan mendekatkan diri ke Allah, kajian ini dapat dibuka untuk umum dengan narasumber yang kompeten dibidangnya. Kajian ini juga dimana kita bisa mengetahui khazanah Islam di masa lalu yakni dengan mengetahui bahasa Arab (kitab kuning) yang

126 Ismail Baharuddin, "Pesantren dan Bahasa Arab," dalam Jurnal Thariqah Ilmiah, Vol. 01, No. 01, Januari 2014, hlm. 6.

127 Hasil wawancara dengan Ustadz KH. Syamsuddin al-Hafidz pada 15 Agustus 2017 di Masjid Darul Muttaqien.

128 Solihin M, Kamus Tasawuf, (Bandung: PT. Remaja Rosdakarya, 2002), hlm. 70.

129 Abbas Pulungan, Pesantren Musthafawiyah Purbabaru Mandailing:Bangunan Keilmuan Islam dan Simbol Masyarakat, (Bandung: Citapustaka Media, 2004), hlm. 6. 
JRTIE: Journal of Research and Thought of Islamic Education

Vol. 1, No. 1, 2018

berisikan wasiat sembilan yang sudah disebutkan dalam kitab ini, barang siapa yang menjaganya, yang mengamalkannya maka yang diharapkan adalah terbukanya hati pintu-pintu paham dan terangnya dada dengan cahaya ilmu.

\section{DAFTAR PUSTAKA}

Amrizal, “Eksistensi Tradisi Kajian Kitab Kuning Dalam Lingkup Perubahan Sosial," dalam Jurnal Sosial Budaya, No. 1, Vol. 13, 2016.

Departemen Pendidikan Diniyah dan Pondok Pesantren, Depag RI, Jurnal Pondok Pesantren (Mihrab), Jakarta: CV. Kaula Muda, 2006.

Farid, Ahmad, Bahrur Ra'iq Zuhdi war Raqa'iq (Zuhud dan Kelembutan Hati), Depok: Pustaka Khazanah Fawa'id, 2016.

Ghozy, Fahrudin, Memungut Amalan Recehan (Rahasia di Balik Amal-Amal Recehan), Yogyakarta: Safirah, 2012.

Ismail, Baharudin, "Pesantren Dan Bahasa Arab," dalam Jurnal Thariqah Ilmiah, Vol. 01, No. 01, Januari 2014.

Margono, S., Metodologi Penelitian Pendidikan, Jakarta: Rineka Cipta, 2000.

Masdub, Sosiologi Pendidikan Agama Islam (Suatu Pendekatan Sosio Religius), Yogyakarta: Aswaja Pressindo, 2015.

Pulungan, Abbas, Pesantren Musthafawiyah Purbabaru Mandailing: Bangunan Keilmuan Islam dan Simbol Masyarakat, Bandung: Citapustaka Media, 2004. Ritonga, Jafar Syahbuddin, “Designing Curriculum, Capacity of Innovation, and Performances: A Study on the Pesantrens in North Sumatra," dalam MIQOT: Jurnal Ilmu-Ilmu Keislaman, Nol. 40, No. 1, 2016.

Shihab, Quraish, EnsiklopediaAl-Qur'an (Kajian Kosakata), Jakarta: Lentera Hati, 2007.

Solihin, M., Kamus Tasawuf, Bandung: PT. Remaja Rosdakarya, 2002.

Subana, M. dan Sudrajat, Dasar-dasar Penelitian Ilmiah, Bandung: Pustaka Setia, 2009.

Van Bruinessen, Martin, Kitab Kuning, Pesantren dan Tarekat, Bandung: Mizan, 1999 